\title{
REGISTER ISTILAH BAHASA INGGRIS BIDANG KONSERVASI DAN PRESERVASI SENI WARISAN BUDAYA
}

\author{
Prima Dona Hapsari \\ Institut Seni Indonesia, Yogyakarta, Indonesia \\ Email: dona.hapsari@gmail.com
}

\section{Article history:}

Submitted Nov 23, 2020

Revised Dec 27, 2020

Accepted Sept 19, 2021

Published Dec 03, 2021

\begin{abstract}
Indonesia is rich in cultural heritage which is well-known in the world and most has been recognized by UNESCO. Cultural heritage can be in the form of objects, such as monuments, artefacts, and regions, or no objects, such as tradition, language, and ritual. The study discusses the register of English terms in the realm of conservation and preservation of cultural heritage art. It is aimed at learning English terms in the realm of conservation and preservation of cultural heritage to enrich English vocabulary, finding the form of specific terms in the field of conservation and preservation of cultural heritage, and providing an alphabetical list for terms in the field of conservation and preservation of cultural heritage in English and Indonesian. It is descriptive qualitative research with discourse analysis as a data analysis technique. Data collection techniques used are identification techniques in journal articles and books that discuss the conservation and preservation of cultural heritage. The use of registers in writing out the language in the field of art conservation and preservation, and a glossary of terms arranged systematically and in alphabetical order are urgently needed by academics, conservators, and students. Besides, the English terms in the field of conservation and preservation of the art of cultural heritage are aimed to facilitate students, lecturers, researchers, conservators, and others in understanding and applying them.
\end{abstract}

Keywords: conservation; cultural heritage; register; terms; preservation 
Prima Dona Hapsari - Register Istilah Bahasa Inggris Bidang Konservasi dan Preservasi Seni Warisan Budaya

\begin{abstract}
ABSTRAK
Indonesia kaya akan warisan budaya yang sudah dikenal dunia dan sebagian besar telah mendapat pengakuan oleh UNESCO. Warisan budaya dapat berupa benda, seperti monumen, artefak, dan kawasan, atau tak benda, seperti tradisi, bahasa, dan ritual. Penelitian ini akan membahas tentang register istilah Bahasa Inggris dalam ranah koservasi dan preservasi seni warisan budaya. Penelitian ini bertujuan untuk menemukan istilah-istilah bahasa Inggris dalam ranah konservasi dan preservasi warisan budaya untuk memperkaya kosa kata bahasa Inggris, menemukan wujud istilah-istilah khusus dalam bidang konservasi dan preservasi warisan budaya, dan memberikan daftar secara alpabetikal untuk istilah-istilah bidang konservasi dan preservasi warisan budaya dalam Bahasa Inggris dan Bahasa Indonesia. Penelitian ini adalah penelitian kualitatif deskriptif dengan analisis wacana sebagai teknik analisis data yang dipakai. Teknik pengumpulan data yang digunakan adalah teknik identifikasi pada artikel jurnal dan buku yang membahas konservasi dan preservasi warisan budaya. Penggunaan register dalam bahasa tulis dalam bidang konservasi dan preservasi dan daftar istilah yang disusun secara bersistem dan menurut abjad sangat dibutuhkan para akademisi, konservator, dan mahasiswa. Selain itu, istilah-istilah dalam bahasa Inggris di bidang ilmu konservasi dan preservasi seni warisan budaya tersebut untuk memudahkan dalam memahami dan menerapkannya.
\end{abstract}

Kata kunci: konservasi; warisan budaya; register; istilah; preservasi

\title{
PENDAHULUAN
}

Indonesia sebagai negara yang kaya akan seni budaya telah mendapat pengakuan dunia internasional dengan beberapa warisan budaya yang ditemukan sejak jaman nenek moyang bangsa Indonesia. UNESCO telah mengakui tujuh belas warisan budaya dan ketiga belas di antaranya adalah warisan budaya tak benda, yaitu batik, keris, pencak silat, wayang kulit, angklung, tari Bali, tari Saman, noken, perahu pinisi, sekaten, lumpia, gamelan, dan sekaten. Saat ini warisan budaya tersebut masih ada dan berkembang, namun ada beberapa yang sudah hampir punah dan memerlukan penanganan dan perhatian khusus. Oleh karena itu, pemerintah Indonesia bekerjasama dengan museum dan balai-balai konservasi dan cagar budaya memiliki program-program guna memberikan informasi kepada masyarakat akan pentingnya melestarikan seni budaya yang 
telah dimiliki oleh bangsa Indonesia dan menjadi kebanggaan di dunia internasional.

Referensi dan sumber pustaka untuk bidang ilmu konservasi dan preservasi seni dan budaya sudah banyak, namun sebagian besar dalam bahasa Inggris. Hal tersebut terkait dengan banyaknya peneliti dan penulis asing yang tertarik mempelajari seni budaya di Indonesia, terutama pada warisan budaya bangsa Indonesia. Misalnya pada istilah untuk preservasi ditemukan istilah damage, humidity, light level, storeroom, temperature, dan lain-lain. Oleh karena itu, terdapat dua permasalahan yang akan diteliti dan dikaji dalam penelitian ini, yaitu menemukan istilah-istilah bahasa Inggris dalam ranah konservasi dan preservasi warisan budaya untuk memperkaya kosa kata Bahasa Inggris serta memberi definisinya dalam Bahasa Indonesia; menentukan wujud istilah-istilah khusus dalam bidang konservasi dan preservasi warisan budaya; dan memberikan daftar secara alpabetikal untuk istilah-istilah bidang konservasi dan preservasi warisan budaya dalam Bahasa Inggris dan Bahasa Indonesia.

Sebagai upaya untuk memberikan pengetahuan dan pemahaman akan pentingnya melestarikan warisan budaya, terutama bagi bangsa Indonesia sendiri, serta lebih mengenalkan warisan budaya Indonesia tersebut di dunia internasional, peneliti memberikan register istilah berbahasa Inggris dengan memberikan defininya dalam Bahasa Indonesia dalam bidang konservasi dan preservasi terhadap warisan budaya, memberikan daftar istilah yang disusun secara bersistem dan menurut abjad yang berguna untuk para akademisi, konservator, dan mahasiswa, serta memberikan istilah-istilah tersebut lebih mudah dipahami dan diterapkan dalam teks maupun tulisan.

Penelitian ini dipandang perlu dan penting untuk dilakukan sebagai salah satu langkah strategis melakukan pelestarian terhadap aset budaya bangsa Indonesia supaya tidak dipergunakan oleh pihak-pihak asing untuk kepentingan mereka sendiri. Bangsa Indonesia harus menyadari bahwa Indonesia sangat kaya akan hal tersebut, dan harus melakukan tindakan preventif menyelamatkan dan melestarikannya dengan memiliki pemahaman akan model dan teknik konservasi 
Prima Dona Hapsari - Register Istilah Bahasa Inggris Bidang Konservasi dan Preservasi Seni Warisan Budaya dan preservasi seni budaya yang tepat dan yang disesuaikan dengan karakter bangsa Indonesia. Selain itu register istilah dalam bidang konservasi dan preservasi warisan budaya ini sangat diperlukan bagi para dosen dan mahasiswa sebagai referensi pendukung terutama untuk penulisan artikel, buku ajar, maupun tugas akhir di perguruan tinggi.

\section{TEORI DAN METODE PENELITIAN}

Kajian mengenai penggunaan register sudah banyak dilakukan oleh para peneliti bahasa. Namun, ada perbedaan pada objek yang akan diteliti sehingga muncullah kajian tentang penggunaaan register istilah bidang tertentu. Pembahasan mengenai register istilah bahasa Inggris untuk bidang konservasi dan preservasi warisan budaya belum dilakukan oleh para peneliti maupun penulis sebelumnya. Pada dasarnya, para peneliti dan penulis lebih banyak membahas metode maupun model konservasi dan preservasi seni daripada membuat register atau daftar istilahistilah yang dipakai sebagai pendukung penulisan ilmiah. Penerapan penggunaan istilah-istilah tersebut mempunyai peranan penting dalam kajian seni budaya dan bermanfaat bagi langkah-langkah strategis dalam upaya pelestarian warisan budaya peninggalan nenek moyang bangsa Indonesia. Demikian juga peranan register istilah berbahasa Inggris ini akan lebih memperkaya pemahaman terhadap sosiolingustik yang menelaah penggunaan bahasa sebagai bagian dari interaksi masyarakat dalam bidang konservasi dan preservasi seni budaya.

Masyarakat sebagai pengguna bahasa sangat terikat satu sama lain. Hal ini disebabkan karena adanya struktur sosial yang mempengaruhi atau menentukan struktur linguistik dan tingkah lakunya (Wardhaugh, 2006:13). Dari pemahaman tersebut kemudian munculah sosiolinguistik yang menelaah hubungan antara bahasa dan masyarakat yang memiliki tujuan untuk memahami struktur bahasa secara lebih baik dan untuk mencari tahu bagaiman bahasa itu bisa berfungsi dalam komunikasi. Lebih jauh ditambahkan oleh Pride dan Holmes bahwa sosiolinguistik sebagai bagian dari kebudayaan dan masyarakat. Sosiolinguistik menelaah penggunaan bahasa sebagai alat interaksi anggota masyarakat dalam kehidupan 
sehari-hari. Dengan kata lain, masyarakat sebagai unsur penting di samping bahasa sendiri dalam penelaahan sosiolinguistik.

Lebih jauh, Trudgill (2000) mengungkapkan sosiolinguistik adalah bagian dari linguistik yang berkaitan dengan bahasa sebagai gejala sosial dan gejala kebudayaan. Dalam hal ini bahasa bukan hanya dianggap sebagai gejala sosial melainkan juga gejala kebudayaan. Implikasinya adalah bahasa dikaitkan dengan kebudayaan masih menjadi cakupan sosiolinguistik, dan ini dapat dimengerti karena setiap masyarakat pasti memiliki kebudayaan tertentu.

Adanya berbagai macam perbedaan dalam masyarakat seperti jenis kelamin, umur, status, dan kelas mengakibatkan berbagai macam variasi bahasa. Manusia dalam masyarakat mempunyai sifat elastis karena manusia bermasyarakat sehingga menempati tempat dan menemui suasana yang sangat bervariasi. Di samping sebabsebab di atas, variasi bahasa juga diakibatkan oleh manusia itu sendiri secara alamiah yang mempunyai daya kreatif. Terjadinya keragaman atau kevariasian bahasa ini bukan hanya disebabkan oleh para penuturnya yang tidak homogen, tetapi juga kegiatan interaksi sosial yang mereka lakukan sangat beragam (Chaer dan Agustina, 2004: 61).

Peran bahasa dipandang penting ketika masyarakat sebagai pemakainya mendorong munculnya keragaman bahasa. Kegiatan yang terdapat dalam masyarakat menciptakan keragaman bahasa di mana setiap kegiatan menghasilkan bahasa dengan ciri khas masing-masing. Bahasa dan ciri-ciri khas yang terbentuk itu dipengaruhi oleh bidang kegiatan tertentu, yang kemudian disebut register (Wijayanti, Desi, 2018:1). Pemakaian istilah bahasa Inggris untuk bidang konservasi dan preservasi mengarahkan pada register yang merupakan salah satu bentuk gejala variasi bahasa yang disebabkan oleh perbedaan bidang pemakaian. Hal ini sejalan dengan Chaer dan Agustina (2010: 68) yang menyatakan bahwa register merupakan variasi bahasa yang digunakan oleh masyarakat tertentu sesuai dengan profesinya. Dan persamaan makna ini juga disampaikan oleh Wardhaug dalam Ngalim (2013: 89) yang menyatakan "Registers are sets of vocabulary items associated with discrete 
Prima Dona Hapsari - Register Istilah Bahasa Inggris Bidang Konservasi dan Preservasi Seni Warisan Budaya occupational or social groups." Register adalah seperangkat perbendaharaan kata yang berkaitan dengan ciri khas pekerjaan dan kelompok.

Lebih jauh, Santoso (2008: 4-5) menyebutkan pendapatnya yang dikutip dari pikiran-pikiran Halliday, seorang ahli bahasa yang memandang bahasa sebagai fenomena sosial, Ada dua hal pokok dalam pengertian register. Pertama, register disamakan dengan gaya (style), yakni variasi dalam tuturan atau tulisan seseorang. Gaya umumnya bervariasi dari yang bersifat sangat akrab sampai yang amat formal menurut jenis situasi, orang, atau pribadi yang dituju, lokasi, topik yang didiskusikan, dan sebagainya. Kedua, register adalah variasi tuturan yang digunakan oleh kelompok tertentu yang biasanya memiliki pekerjaan yang sama atau kepentingan yang sama (Halliday \& Hasan dalam Santoso, 2008:4). Register dapat diketahui dari karakteristik leksikogramatis dan fonologis yang secara khusus menyertai atau menyatakan makna-makna tertentu. Register merupakan variasi bahasa yang disebabkan oleh adanya sifat-sifat khas keperluan pemakainya, misalnya bahasa tulis terdapat bahasa iklan, bahasa tunjuk, bahasa artikel, dan sebagainya, dalam bahasa lisan terdapat bahasa lawak, bahasa politik, bahasa doa, bahasa pialang dan sebagainya. Contoh dalam bidang konservasi adalah chalking: adanya bubuk yang terdapat di permukaan cat setelah terpapar elemen.

Register yang memiliki variasi bahasa dalam tuturan maupun tulisan terdapat pola-pola bahasa yang sama. Pola-pola bahasa itu dapat dianalisis secara deskriptif. Pola-polanya dibatasi oleh makna tersebut yang dipergunakan oleh penuturnya untuk berkomunikasi. Lebih lanjut, variasi bahasa atau ragam bahasa adalah penggunaan bahasa menurut pemakainya, yang berbeda-beda menurut topik yang dibicarakan, menurut hubungan pembicara, kawan bicara, dan orang yang dibicarakan serta menurut medium pembicaraan (KBBI, 2003: 920). Menurut Halliday (1994 :54), register merupakan konsep semantik yang dapat didefinisikan sebagai suatu susunan makna yang dihubungkan secara khusus dengan susunan tertentu dari medan, pelibat, dan sarana. Ungkapan susunan makna register termasuk juga ungkapan dari ciri leksiko gramatis dan fonologis yang secara khusus menyertai atau menyatakan makna- makna. 
Dari pengertian tersebut, register dipahami sebagai konsep semantik yaitu sebagai susunan makna yang dikaitkan secara khusus dengan susunan situasi tertentu. Konsep situasi menurut Halliday mengacu pada tiga hal, yaitu (1) medan (field), (2) pelibat (tenor), (3) sarana (mode). Medan mengacu pada hal yang sedang terjadi atau pada saat tindakkan berlangsung, apa sesungguhnya yang sedang disebutkan oleh para pelibat (bahasa termasuk sebagai unsur pokok tertentu).

Penelitian ini adalah penelitian kualitatif. Masalah penelitian ini dikaji dengan menggunakan pendekatan teoritis sosiolinguistik dan wacana tulis. Implikasi dari pendekatan itu adalah penelitian ini memfokuskan kajian pada bahasa yang ada pada tulisan artikel dan buku konservasi dan preservasi bertema warisan budaya. Secara metodelogis, pendekatan ini menggunakan pendekatan kualitatif deskriptif. Artikel dalam kedua hal tersebut adalah salah satu bentuk wacana. Wacana adalah merupakan satuan bahasa yang paling besar yang digunakan dalam komunikasi. Sumber data dari penelitian ini adalah berupa buku-buku dan artikel dalam bidang konservasi dan preservasi, khususnya warisan budaya berbahasa Inggris. Teknik pengumpulan data yang digunakan adalah teknik identifikasi. Artikel yang ada pada kedua sumber teks tersebut dibaca secara seksama untuk mengidentifikasi penggunaan register yang ada di dalamnya. Artikel yang ditemukan terdapat register, dipilih sebagai data penelitian.

Pada tahap analisis data, digunakan metode analisis wacana. Menurut Stubbs (1983:1) analisis wacana adalah suatu kajian yang meneliti atau menganalisis bahasa yang digunakan secara alamiah, baik dalam bentuk tulis maupun lisan. Analisis wacana menekankan kajian penggunaan bahasa dalam konteks sosial, khususnya dalam interaksi antarpenutur. Senada dengan Tannen, dkk (2015) dalam hal ini menyatakan bahwa analisis wacana merupakan kajian yang membahas tentang wacana, sedangkan wacana itu adalah bahasa yang digunakan untuk berkomunikasi. Berdasarkan tujuan berkomunikasi, wacana dapat dibedakan menjadi wacana deskripsi, eksposisi, argumentasi, persuasi, dan narasi. 
Prima Dona Hapsari - Register Istilah Bahasa Inggris Bidang Konservasi dan Preservasi Seni Warisan Budaya

\section{HASIL DAN PEMBAHASAN}

Kajian mengenai penggunaan register sudah banyak dilakukan oleh para peneliti bahasa. Namun, ada perbedaan pada objek yang akan diteliti sehingga muncullah kajian tentang penggunaaan register istilah bidang tertentu. Pembahasan mengenai register istilah bahasa Inggris untuk bidang konservasi dan preservasi warisan budaya belum dilakukan oleh para peneliti maupun penulis sebelumnya. Pada dasarnya, para peneliti dan penulis lebih banyak membahas metode maupun model konservasi dan preservasi seni daripada membuat register atau daftar istilahistilah yang dipakai sebagai pendukung penulisan ilmiah. Penerapan penggunaan istilah-istilah tersebut mempunyai peranan penting dalam kajian seni budaya dan bermanfaat bagi langkah-langkah strategis dalam upaya pelestarian warisan budaya peninggalan nenek moyang bangsa Indonesia. Demikian juga peranan register istilah berbahasa Inggris ini akan lebih memperkaya pemahaman terhadap sosiolingustik yang menelaah penggunaan bahasa sebagai bagian dari interaksi masyarakat dalam bidang konservasi dan preservasi seni budaya.

Masyarakat sebagai pengguna bahasa sangat terikat satu sama lain. Hal ini disebabkan karena adanya struktur sosial yang mempengaruhi atau menentukan struktur linguistik dan tingkah lakunya (Wardhaugh, 2006:13). Dari pemahaman tersebut kemudian munculah sosiolinguistik yang menelaah hubungan antara bahasa dan masyarakat yang memiliki tujuan untuk memahami struktur bahasa secara lebih baik dan untuk mencari tahu bagaiman bahasa itu bisa berfungsi dalam komunikasi. Lebih jauh ditambahkan oleh Pride dan Holmes bahwa sosiolinguistik sebagai bagian dari kebudayaan dan masyarakat. Sosiolinguistik menelaah penggunaan bahasa sebagai alat interaksi anggota masyarakat dalam kehidupan sehari-hari. Dengan kata lain, masyarakat sebagai unsur penting di samping bahasa sendiri dalam penelaahan sosiolinguistik.

Lebih jauh, Trudgill (2000) mengungkapkan sosiolinguistik adalah bagian dari linguistik yang berkaitan dengan bahasa sebagai gejala sosial dan gejala kebudayaan. Dalam hal ini bahasa bukan hanya dianggap sebagai gejala sosial melainkan juga gejala kebudayaan. Implikasinya adalah bahasa dikaitkan dengan 
kebudayaan masih menjadi cakupan sosiolinguistik, dan ini dapat dimengerti karena setiap masyarakat pasti memiliki kebudayaan tertentu.

Adanya berbagai macam perbedaan dalam masyarakat seperti jenis kelamin, umur, status, dan kelas mengakibatkan berbagai macam variasi bahasa. Manusia dalam masyarakat mempunyai sifat elastis karena manusia bermasyarakat sehingga menempati tempat dan menemui suasana yang sangat bervariasi. Di samping sebabsebab di atas, variasi bahasa juga diakibatkan oleh manusia itu sendiri secara alamiah yang mempunyai daya kreatif. Terjadinya keragaman atau kevariasian bahasa ini bukan hanya disebabkan oleh para penuturnya yang tidak homogen, tetapi juga kegiatan interaksi sosial yang mereka lakukan sangat beragam (Chaer dan Agustina, 2004: 61).

Peran bahasa dipandang penting ketika masyarakat sebagai pemakainya mendorong munculnya keragaman bahasa. Kegiatan yang terdapat dalam masyarakat menciptakan keragaman bahasa di mana setiap kegiatan menghasilkan bahasa dengan ciri khas masing-masing. Bahasa dan ciri-ciri khas yang terbentuk itu dipengaruhi oleh bidang kegiatan tertentu, yang kemudian disebut register (Wijayanti, Desi, 2018:1). Pemakaian istilah bahasa Inggris untuk bidang konservasi dan preservasi mengarahkan pada register yang merupakan salah satu bentuk gejala variasi bahasa yang disebabkan oleh perbedaan bidang pemakaian. Hal ini sejalan dengan Chaer dan Agustina (2010: 68) yang menyatakan bahwa register merupakan variasi bahasa yang digunakan oleh masyarakat tertentu sesuai dengan profesinya. Dan persamaan makna ini juga disampaikan oleh Wardhaug dalam Ngalim (2013: 89) yang menyatakan "Registers are sets of vocabulary items associated with discrete occupational or social groups." Register adalah seperangkat perbendaharaan kata yang berkaitan dengan ciri khas pekerjaan dan kelompok.

Lebih jauh, Santoso (2008: 4-5) menyebutkan pendapatnya yang dikutip dari pikiran-pikiran Halliday, seorang ahli bahasa yang memandang bahasa sebagai fenomena sosial, Ada dua hal pokok dalam pengertian register. Pertama, register disamakan dengan gaya (style), yakni variasi dalam tuturan atau tulisan seseorang. Gaya umumnya bervariasi dari yang bersifat sangat akrab sampai yang amat formal 
Prima Dona Hapsari - Register Istilah Bahasa Inggris Bidang Konservasi dan Preservasi Seni Warisan Budaya menurut jenis situasi, orang, atau pribadi yang dituju, lokasi, topik yang didiskusikan, dan sebagainya. Kedua, register adalah variasi tuturan yang digunakan oleh kelompok tertentu yang biasanya memiliki pekerjaan yang sama atau kepentingan yang sama (Halliday \& Hasan dalam Santoso, 2008:4). Register dapat diketahui dari karakteristik leksikogramatis dan fonologis yang secara khusus menyertai atau menyatakan makna-makna tertentu. Register merupakan variasi bahasa yang disebabkan oleh adanya sifat-sifat khas keperluan pemakainya, misalnya bahasa tulis terdapat bahasa iklan, bahasa tunjuk, bahasa artikel, dan sebagainya, dalam bahasa lisan terdapat bahasa lawak, bahasa politik, bahasa doa, bahasa pialang dan sebagainya. Contoh dalam bidang konservasi adalah chalking: adanya bubuk yang terdapat di permukaan cat setelah terpapar elemen.

Register yang memiliki variasi bahasa dalam tuturan maupun tulisan terdapat pola-pola bahasa yang sama. Pola-pola bahasa itu dapat dianalisis secara deskriptif. Pola-polanya dibatasi oleh makna tersebut yang dipergunakan oleh penuturnya untuk berkomunikasi. Lebih lanjut, variasi bahasa atau ragam bahasa adalah penggunaan bahasa menurut pemakainya, yang berbeda-beda menurut topik yang dibicarakan, menurut hubungan pembicara, kawan bicara, dan orang yang dibicarakan serta menurut medium pembicaraan (KBBI, 2003: 920). Menurut Halliday (1994 :54), register merupakan konsep semantik yang dapat didefinisikan sebagai suatu susunan makna yang dihubungkan secara khusus dengan susunan tertentu dari medan, pelibat, dan sarana. Ungkapan susunan makna register termasuk juga ungkapan dari ciri leksiko gramatis dan fonologis yang secara khusus menyertai atau menyatakan makna- makna.

Dari pengertian tersebut, register dipahami sebagai konsep semantik yaitu sebagai susunan makna yang dikaitkan secara khusus dengan susunan situasi tertentu. Konsep situasi menurut Halliday mengacu pada tiga hal, yaitu (1) medan (field), (2) pelibat (tenor), (3) sarana (mode). Medan mengacu pada hal yang sedang terjadi atau pada saat tindakkan berlangsung, apa sesungguhnya yang sedang disebutkan oleh para pelibat (bahasa termasuk sebagai unsur pokok tertentu). 
Dalam menganalisis dan memahami teks terutama di bidang konservasi dan preservasi warisan budaya, istilah-istilah asing berbahasa Inggris sangat banyak dijumpai terutama istilah-istilah khusus yang belum umum dipakai. Menurut Van Dijk dalam Titscher, Stefan, dkk (2009:48), teks merupakan rangkaian-rangkaian kalimat yang memiliki struktur makro yang dinyatakan sebagai kerangka proposisi dan tematik dasar yang memungkinkan teks bisa menyatu. Penelitian ini berfokus pada variasi berupa register yang ada dalam buku-buku referensi konservasi dan preservasi warisan budaya dan artikel-artikel ilmiah yang mengkaji kedua bidang tersebut. Dengan kata lain istilah-istilah konservasi dan preservasi warisan budaya akan sangat membantu peneliti, akademisi, penulis, dan mahasiswa untuk lebih mendalami maksud dari istilah-istilah tersebut yang berasal dari Bahasa Inggris yang akan dijelaskan maknanya dalam Bahasa Indonesia.

Berikut ini adalah beberapa istilah-istilah asing bidang konservasi dan preservasi seni warisan budaya yang dihimpun dari beberapa buku teks dan bacaan tentang konservasi dan preservasi seni.

Tabel 1. Daftar Istilah Bidang Konservasi dan Preservasi Seni Warisan Budaya

\begin{tabular}{|c|c|c|c|}
\hline English & Meaning & Bahasa Indonesia & Arti \\
\hline $\begin{array}{l}\text { Art conservation } \\
\text { and restoration }\end{array}$ & $\begin{array}{l}\text { Any attempt to conserve } \\
\text { and repair architecture, } \\
\text { paintings, drawings, } \\
\text { prints, sculptures, and } \\
\text { objects of the decorative } \\
\text { arts (furniture, } \\
\text { glassware, metalware, } \\
\text { textiles, ceramics, and so } \\
\text { on) that have been } \\
\text { adversely affected by } \\
\text { negligence, willful } \\
\text { damage, or, more } \\
\text { usually, the inevitable } \\
\text { decay caused by the } \\
\text { effects of time and } \\
\text { human use on the } \\
\text { materials of which they } \\
\text { are made. }\end{array}$ & $\begin{array}{ll}\text { Koservasi } & \text { dan } \\
\text { restorasi seni } & \end{array}$ & 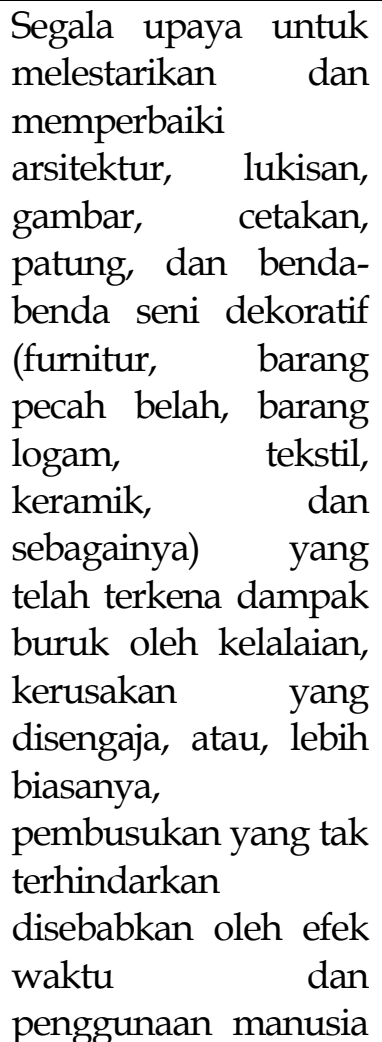 \\
\hline
\end{tabular}


Prima Dona Hapsari - Register Istilah Bahasa Inggris Bidang Konservasi dan Preservasi Seni Warisan Budaya

\begin{tabular}{|c|c|c|c|}
\hline & & & $\begin{array}{l}\text { pada bahan yang } \\
\text { mereka buat. }\end{array}$ \\
\hline Damage & $\begin{array}{l}\text { Physical harm caused to } \\
\text { something in such a way } \\
\text { as to impair its value, } \\
\text { usefulness, or normal } \\
\text { function. }\end{array}$ & Kerusakan & $\begin{array}{lr}\begin{array}{l}\text { kerugian fisik } \\
\text { disebabkang } \\
\text { sesuatu sedemikian } \\
\text { rupa }\end{array} \\
\text { merusak nehingga } \\
\text { kegunaan, atau fungsi } \\
\text { normal }\end{array}$ \\
\hline Demolition & $\begin{array}{l}\text { Action/s of removing } \\
\text { existing materials and/or } \\
\text { part/s of the building. }\end{array}$ & Pembongkaran & $\begin{array}{l}\text { Tindakan } \\
\text { mengeluarkan } \\
\text { material dan / atau } \\
\text { bagian bangunan } \\
\text { yang ada. }\end{array}$ \\
\hline $\begin{array}{l}\text { Deterioration } \\
\text { factors }\end{array}$ & $\begin{array}{l}\text { The ratio of the } \\
\text { calculated emission level } \\
\text { at the point representing } \\
\text { the full useful life to the } \\
\text { calculated emission level } \\
\text { at zero hours. }\end{array}$ & Faktor penyusutan & $\begin{array}{l}\text { Rasio tingkat emisi } \\
\text { yang dihitung pada } \\
\text { titik yang mewakili } \\
\text { masa manfaat penuh } \\
\text { dengan tingkat emisi } \\
\text { yang dihitung pada } \\
\text { nol jam. }\end{array}$ \\
\hline $\begin{array}{l}\text { Environmental } \\
\text { impact }\end{array}$ & $\begin{array}{l}\text { Any change to the } \\
\text { environment, whether } \\
\text { adverse or beneficial, } \\
\text { resulting from a facility's } \\
\text { activities, products, or } \\
\text { services. }\end{array}$ & Dampak lingkungan & $\begin{array}{l}\text { Setiap perubahan } \\
\text { pada lingkungan, baik } \\
\text { yang merugikan atau } \\
\text { menguntungkan, } \\
\text { yang dihasilkan dari } \\
\text { kegiatan, produk, } \\
\text { atau layanan fasilitas. }\end{array}$ \\
\hline $\begin{array}{l}\text { Framed art } \\
\text { storage }\end{array}$ & $\begin{array}{l}\text { A place to put framed art } \\
\text { items vertically. }\end{array}$ & $\begin{array}{l}\text { Wadah } \\
\text { penyimpanan } \\
\text { barang } \\
\text { berbingkai }\end{array}$ & $\begin{array}{lr}\text { wadah } & \text { penyimpanan } \\
\text { barang } & \text { seni } \\
\text { berbingkai } & \text { yang } \\
\text { disusun } & \text { secara } \\
\text { vertikal } & \\
\end{array}$ \\
\hline Humidity & $\begin{array}{l}\text { The concentration of } \\
\text { water vapour present in } \\
\text { the air. Water vapour, } \\
\text { the gaseous state of } \\
\text { water, is generally } \\
\text { invisible to the human } \\
\text { eye. }\end{array}$ & Kelembaban & $\begin{array}{l}\text { konsentrasi uap air } \\
\text { yang berada di udara. } \\
\text { Biasanya berupa uap } \\
\text { air, keadaan gas } \\
\text { dalam air, umumnya } \\
\text { tidak terlihat oleh } \\
\text { mata manusia. }\end{array}$ \\
\hline $\begin{array}{l}\text { Light level, or } \\
\text { Illuminance }\end{array}$ & $\begin{array}{l}\text { The amount of light } \\
\text { measured in a plane } \\
\text { surface (or the total } \\
\text { luminous flux incident } \\
\text { on a surface, per unit } \\
\text { area. }\end{array}$ & $\begin{array}{l}\text { Tingkat } \\
\text { pencahayaan, } \\
\text { iluminasi }\end{array}$ & 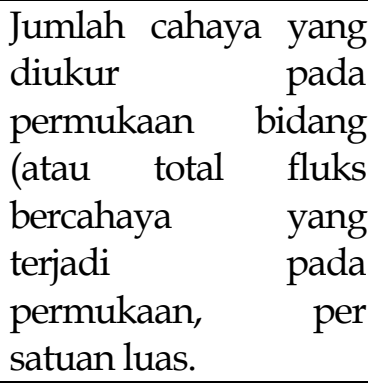 \\
\hline
\end{tabular}




\begin{tabular}{|c|c|c|c|}
\hline Noncorrosive & $\begin{array}{l}\text { Any products which do } \\
\text { not have the power } \\
\text { to corrode. }\end{array}$ & $\begin{array}{l}\text { Tidak mengandung } \\
\text { korosif }\end{array}$ & $\begin{array}{lr}\text { Semua produk yang } \\
\text { tidak } \quad \text { memiliki } \\
\text { kekuatan } & \text { untuk } \\
\text { menimbulkan korosi. }\end{array}$ \\
\hline $\begin{array}{l}\text { Preventive } \\
\text { conservation }\end{array}$ & $\begin{array}{l}\text { All measures and actions } \\
\text { aimed at avoiding and } \\
\text { minimizing future } \\
\text { deterioration or loss. }\end{array}$ & Konservasi preventif & 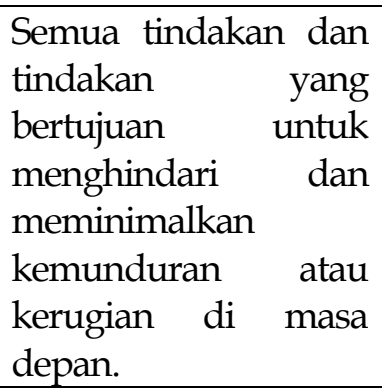 \\
\hline Rehabilitation & $\begin{array}{l}\text { Act or process of making } \\
\text { possible a (new) } \\
\text { compatible use for a } \\
\text { property. It can include } \\
\text { element } \\
\text { modernization as well as } \\
\text { some extension works } \\
\text { with even major } \\
\text { structural alterations. }\end{array}$ & Rehabilitasi & $\begin{array}{l}\text { Tindakan atau proses } \\
\text { yang memungkinkan } \\
\text { penggunaan (baru) } \\
\text { yang kompatibel } \\
\text { untuk properti. Ini } \\
\text { dapat mencakup } \\
\text { elemen modernisasi } \\
\text { serta beberapa karya } \\
\text { ekstensi bahkan } \\
\text { dengan perubahan } \\
\text { struktural besar. }\end{array}$ \\
\hline Storeroom & $\begin{array}{l}\text { A room or space for the } \\
\text { storing of goods or } \\
\text { supplies. }\end{array}$ & $\begin{array}{l}\text { Gudang } \\
\text { penyimpanan }\end{array}$ & $\begin{array}{lrr}\text { Ruang } & \text { atau } & \text { tempat } \\
\text { untuk } & \text { menyimpan } \\
\text { barang } & \text { atau } \\
\text { persediaan. } & \\
\end{array}$ \\
\hline $\begin{array}{l}\text { Tangible } \\
\text { Cultural } \\
\text { Heritage }\end{array}$ & $\begin{array}{lr}\text { Physical } & \text { artifacts } \\
\text { produced, maintained } \\
\text { and } & \text { transmitted } \\
\text { intergenerationally in a } \\
\text { society. }\end{array}$ & $\begin{array}{l}\text { Warisan } \quad \text { Budaya } \\
\text { Nyata }\end{array}$ & $\begin{array}{l}\text { Artefak fisik yang } \\
\text { diproduksi, } \\
\text { dipelihara, dan } \\
\text { ditransmisikan secara } \\
\text { lintas generasi dalam } \\
\text { suatu masyarakat. }\end{array}$ \\
\hline Temperature & $\begin{array}{l}\text { A measure of the } \\
\text { warmth or coldness of an } \\
\text { object or substance with } \\
\text { reference to some } \\
\text { standard value. }\end{array}$ & Temperatur & $\begin{array}{l}\text { Ukuran kehangatan } \\
\text { atau kedinginan dari } \\
\text { suatu benda atau zat } \\
\text { dengan mengacu } \\
\text { pada beberapa nilai } \\
\text { standar. }\end{array}$ \\
\hline
\end{tabular}

Beberapa istilah di atas disusun secara alfabetikal dengan memberikan arti baik dalam bahasa Inggris dan bahasa Indonesia yang memudahkan dalam pemahaman pemakaiannya.

Daftar istilah dalam bidang konservasi dan preservasi seni warisan budaya bisa dikatakan sangat variatif sesuai dengan materi teks wacana bidang yang 
Prima Dona Hapsari - Register Istilah Bahasa Inggris Bidang Konservasi dan Preservasi Seni Warisan Budaya dirujuk. Dalam penyusunan daftar istilah ini, banyak istilah khusus yang mendapat modifikasi kata yang tidak berdiri sendiri sehingga memiliki makna yang sedikit berbeda dengan istilah yang dipergunakan pada umumnya.

\section{SIMPULAN}

Penggunaan register dalam bahasa tulis dalam bidang konservasi dan preservasi, dan daftar istilah yang disusun secara bersistem dan menurut abjad sangat dibutuhkan para akademisi, konservator, dan mahasiswa. Selain itu, istilahistilah dalam bahasa Inggris di bidang ilmu konservasi dan preservasi seni warisan budaya tersebut untuk memudahkan dalam memahami dan menerapkannya. Beberapa istilah disusun dengan merujuk kepada teks wacana bidang konservasi dan preservasi seni warisan budaya yang memiliki kekhususan baik istilah maupun maknanya. Penulisan istilah-istilah tersebut memuat unsurunsur yang khas dalam pemakaiannya, misalnya framed art store, di mana istilah ini banyak ditemui untuk bidang konservasi dan preservasi seni.

Register istilah konservasi dan preservasi seni warisan budaya bisa disusun untuk membuat kamus khusus bidang konservasi dan preservasi warisan budaya yang berguna bagi pengembangan keilmuan ini, terutama juga membantu kaum akademisi, peneliti, koservator dan preservator. Selain itu, analisis wacana pada bidang konservasi dan preservasi seni budaya akan memberikan referensi baru dalam penerapkan dan penggunaan istilah tersebut secara tepat.

\section{ACKNOWLEDGEMENT}

Penulis mengucapkan terima kasih kepada Lembaga Penelitian dan Pengabdian kepada Masyarakat, Institut Seni Indonesia Yogyakarta atas dukungan pendanaan untuk penelitian ini yang sudah terlaksana pada 2020.

\section{DAFTAR PUSTAKA}

Chaer, A., \& Agustina, L. (2010). Sosiolinguistik: Edisi Revisi. Jakarta: Rineka Cipta. 
Halliday, M.A.K. \& Hasan, R. (1992). Bahasa, konteks, dan teks: aspek-aspek bahasa dalam pandangan semiotik sosial. (terjemahan oleh Barori Tou). Dalam Santoso, A. Jejak Halliday dalam linguistik kritis dan analisis wacana kritis (hlm 4-5). Malang: Universitas Negeri Malang.

Halliday, M. A. K. (2003). On language and linguistics (Vol. 3). A\&C Black.

KBBI, E. K. (2003). Jakarta: Balai Pustaka.

Latifa, Azmi and -, Drs. Agus Budi Wahyudi, M.Hum. (2019) Register Fashion Busana Wanita Pada Rubrik Mode Surat Kabar Solopos Edisi Januari-Juni 2017 Dan Implementasinya Dalam Pembelajaran Di Smk. Skripsi thesis, Universitas Muhammadiyah Surakarta.

Ngalim, A. (2013). Sosiolinguistik: suatu kajian fungsional dan analisisnya. Surakarta: PBSID FKIP UMS.

Santoso, A. (2008). Jejak Halliday dalam linguistik kritis dan analisis wacana kritis. Jurnal Bahasa dan Seni, 36(1), 1-14.

Stubb, M. (1983). Discourse analysis. Chicago: The University of Chicago.

Tannen, D., Hamilton, H. E., \& Schiffrin, D. (Eds.). (2015). The handbook of discourse analysis (Vol. 1). Malden^ eMA MA: Wiley Blackwell.

Trudgill, P. (2000). Sociolinguistics: An introduction to language and society. Penguin UK.

Van Dijk, Teun A. (1980). Textwissenshaft. Eine interdisziplinare Einfuhrung dalam Titscher, S., Meyer, M., Wodak, R., \& Vetter, E. (2000). Methods of text and discourse analysis. London: Sage Publications.

Wijayanti, D. (2018). Register perfilman dalam kegiatan syuting film di rumah produksi MD Pictures. (Unpublished Thesis). FKIP Universitas Negeri Jember, Jember. 